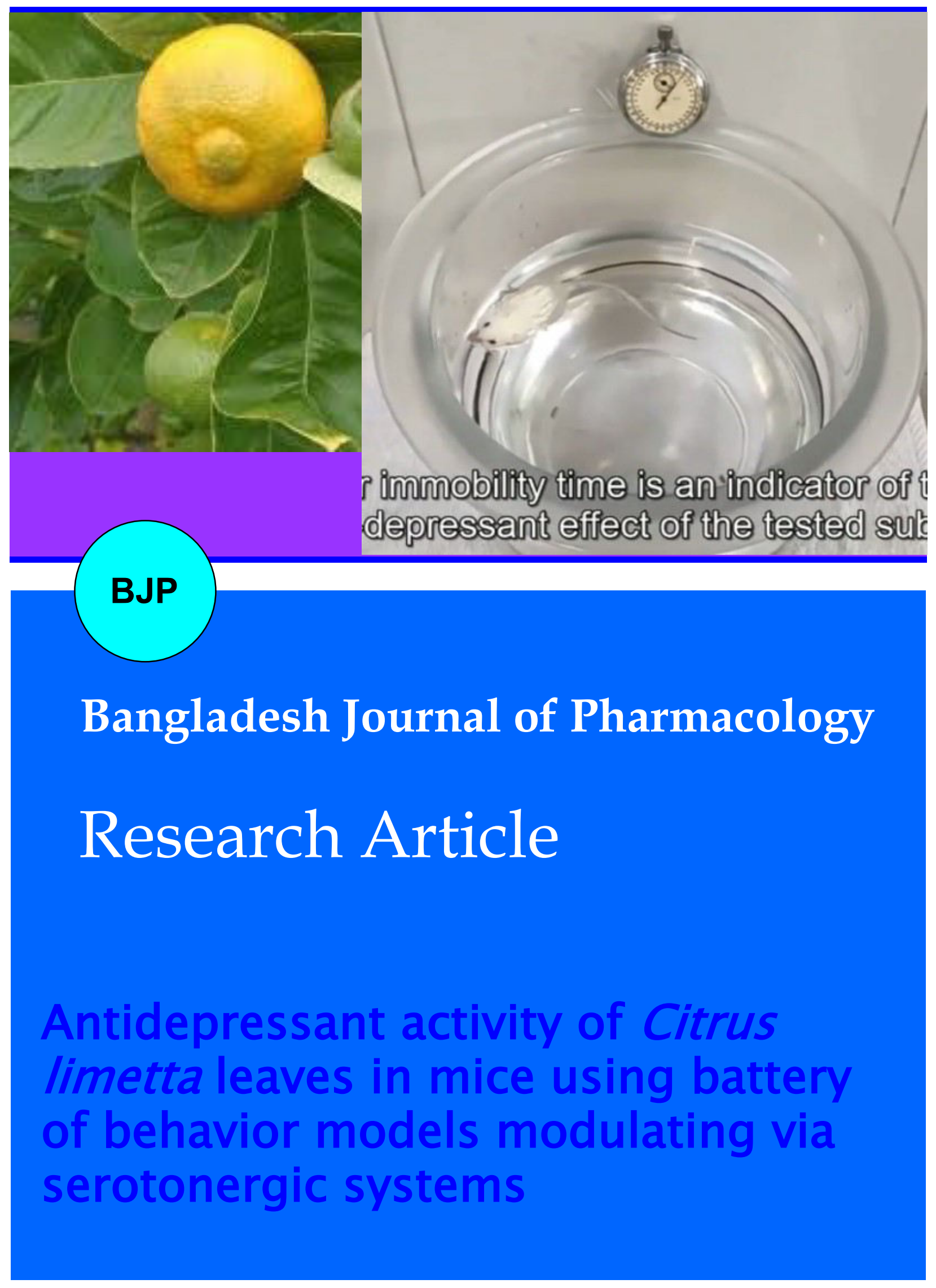




\title{
Antidepressant activity of Citrus limetta leaves in mice using battery of behavior models modulating via serotonergic systems
}

\author{
Jaspreet Kaur, Manisha Bhatia and Parminder Nain
}

M. M. College of Pharmacy, Maharishi Markandeshwar (Deemed to be University), Mullana-Ambala (Haryana) 133207, India.

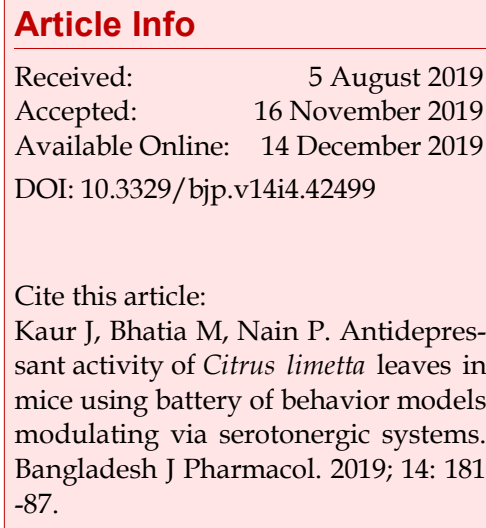

\begin{abstract}
The methanolic extract of Citrus limetta leaves was estimated in the present study for antidepressant activity. This activity was evaluated by using the rat behavioral model i.e. forced swimming and tail suspension model for 14 days, with estimation of neurotransmitters in animals brain. The sedative effect was evaluated by actophotometer. The extract $(200 \mathrm{mg} / \mathrm{kg})$ administered orally showed significant $(\mathrm{p}<0.05)$ decrease in immobility time against the standard drug fluoxetine $(20 \mathrm{mg} / \mathrm{kg}$, i.p), and imipramine $(15 \mathrm{mg} / \mathrm{kg}$, i.p.) respectively but no significant reduction was found in the locomotor activity against diazepam (2 $\mathrm{mg} / \mathrm{kg}$, i.p.). In depression, the brain reflected low monoamines level like release of norepinephrine, dopamine and serotonin but 14 days after successive administration of the extract, their levels were significantly increased. In conclusion, C. limetta showed significant anti-depressant activity.
\end{abstract}

\section{Introduction}

Depression is considered as a mood disorder in which mixed feelings of sadness, loss of appetite, frustration, fatigue and anger interfere with day to day life. The causes are complex and involve a combination of miscellaneous factors such as biologic, genetic, and environmental. People suffering from depression may have abnormal levels of certain monoamine transmitter in brain, including serotonin, acetylcholine, and catecholamine (such as dopamine) (Gold et al., 1988). Numerous synthetic drugs are being used as the standard treatment for this heterogeneous mood disorder but they cause severe adverse effects (Hadizadeh et al., 2009).

In recent years, the search for novel pharmacotherapy agents obtained from medicinal plants like Curcuma longa (Yu et al., 2002), Emblica officinalis (Sharma and Nain., 2011), Ginkgo biloba (Rojas et al., 2011), grape (Rabiei et al., 2017), Withania somnifera (Bhattacharya et al., 2000), etc for psychiatric illnesses has progressed, which has been reflected by experimentation on large number of herbal medicines in a battery of animal models.

Citrus limetta is a species of genus Citrus belonging to family Rutaceae. Citrus plants are rich in naturallyoccurring flavonoids (Cao et al., 1997). A variety of vital bioflavonoids like hesperidin, narirutin, naringin, neohesperidin, eriocitrin, neoeriocitrin, rutin, diosmin, neoponcirin, and nobiletin are abundant in these citrus plants and have proved their efficacy as most prominent cancer preventing agents (Albach et al., 1969; Castillo et al., 1992; Jourdan et al., 1985; Kawaii et al., 1999). Amongst the citrus bioactive flavonoids, the flavanone and polymethoxy flavones glycosides attract significant attention for their constituents and biological activities (Tripoli et al., 2007). They possess a wide variety of biological activities through inhibition of key enzymes in mitochondrial respiration like in treatment of coronary heart disease, anti-spasmolytic, anti-inflammatory, free radical scavengers, estrogenic, cytotoxic, antitumor, antihyperglycemic, larvicidal, antifungal and antibacterial activities (Harborne and Williams, 
2000). It has been revealed by traditional and ethno medicinal literature that fruit and leaves of this important species is very effective in treating different pathologies and ailments such as common cold, fever, control of cholesterol, regulation of inflammatory and digestive disorders, prevention and treatment of skin problems and a remarkable modulator of blood pressure (KunduSen et al., 2010; Perez et al., 2010). Phytochemical profile and traditional use of C. limetta as a multipurpose medicinal agent appealed us to scientifically evaluate its use as an anti-depressant.

\section{Materials and Methods}

\section{Plant material}

The leaves of C. limetta were collected from CDL National herbal park, Yamunanagar, Haryana in AprilMay, 2009 and authenticated by NISCAIR (NISCAIR/ RHMD/CONSULT/2009-10/1347/150). All chemicals were obtained from the Sigma Aldrich.

\section{Preparation of extracts}

The leaves of C. limetta were shed dried, powdered and subjected to successive solvent extraction with four different solvents namely namely petroleum ether (40$\left.60^{\circ} \mathrm{C}\right)$, chloroform $\left(61^{\circ} \mathrm{C}\right)$, methanol $\left(65^{\circ} \mathrm{C}\right)$ and water in soxhlet extractor.

\section{Phytochemical screening}

The extracts were screened for different classes of phytoconstituents such as alkaloids, triterpenoid, carbohydrates, flavonoids and tannins using standard procedures (Trease and Evans, 2002; Edeoga et al., 2005).

\section{Animals}

Swiss albino mice of either sex (approximately 3 months old and weighing about 20-25 g were collected from the institutional animal house and kept under standard laboratory conditions (maintained at ambient temperature of $23^{\circ} \mathrm{C}$ with changes of light and dark every 12 hours and constant access to food and water). The animals were housed at least one week in the laboratory animal room before testing.

\section{Drugs}

Fluoxetine $(20 \mathrm{mg} / \mathrm{kg})$, imipramine $(15 \mathrm{mg} / \mathrm{kg})$ and diazepam $(2 \mathrm{mg} / \mathrm{kg}$ ) were used as standard drugs for forced swimming test, tail suspension test and locomotor activity respectively. These drugs were dissolved in $2 \%$ aqueous Tween 80 suspension and administered orally.

\section{Acute toxicity study}

Acute oral toxicity study of the methanolic extract of $C$. limetta was carried out in Swiss albino mice (20-25 g) of either sex. Mice comprising 6 animals in each group, fasted for 18 hours before experiment, were given the methanol extract (50, 100, 200, 400, 500, 1000, and 2000 $\mathrm{mg} / \mathrm{kg}$ ) p.o. The control group received distilled water $10 \mathrm{~mL} / \mathrm{kg}$ p.o. Mice were closely observed for 2 hours post-treatment for any signs of toxicity as well as behavioural changes. The rate of mortality shown within 24 hours was recorded. The surviving mice were further observed for another 7 days for any significant signs of delayed toxicity. The lethal dose $50\left(\mathrm{LD}_{50}\right)$ value was estimated by log-probit analysis (Akindele and Adeyemi, 2006).

\section{Preparation of test doses}

The methanolic extract of $C$. limetta did not cause death and was found to be completely nontoxic up to a dose of $2 \mathrm{~g} / \mathrm{kg}$. Thus, it was considered to be safe for use. One-tenth of this dose, i.e., $200 \mathrm{mg} / \mathrm{kg}$ body weight and half of this one-tenth dose, i.e., $100 \mathrm{mg} / \mathrm{kg}$, were used as minimum dose for the elucidation of different pharmacological activities.

Based on acute toxicity study, 100, 200, $400 \mathrm{mg} / \mathrm{kg}$ of the extracts were prepared by suspending the dried extracts in vehicle ( $2 \%$ aqueous Tween 80 suspension). The doses of methanol extracts were so adjusted as to administer $0.5 \mathrm{~mL}$ of the suspension of extracts. Diazepam $2 \mathrm{mg} / \mathrm{kg}$ suspended in the vehicle was used as standard anxiolytic. The suspending vehicle $(0.5 \mathrm{~mL})$ was used as control.

\section{Experimental protocol}

All mice were randomly divided into 18 groups. Each group contained 6 mice.

\section{Tail suspension test}

The tail suspension test was the second effective method for evaluating the antidepressant effect of the methanol extract. Thirty min after the standard drug or vehicle administered, mice were subjected to the test. Each animal was individually suspended in the wooden box with the help of hanging clip $50 \mathrm{~cm}$ above the floor and $1 \mathrm{~cm}$ part of the tail was clipped. During the test each animal taken was both acoustically and visually isolated from other animals. The total period (six minutes) of immobility/mobility shown by the animals was recorded manually. It was observed that each animal showed vigorous movement during the initial $2 \mathrm{~min}$ period out of the total $6 \mathrm{~min}$ testing period. The immobility of animals was manually recorded during the next 4 min of total experimental period. After the initial period of vigorous motor activity, the mice became still and the time of immobility was measured with a stopwatch, for a total duration of 6 min. The testing animals were considered immobile when they hung passively and completely motionless (Steru et al., 1985). 


\section{Box 1: Forced swimming test}

\section{Principle}

Measurement of immobility time is carried out by observing water.

\section{Requirements}

Glass cylinder (diameter $25 \mathrm{~cm}$, height $25 \mathrm{~cm}$ ); Methanol extract; Mouse; Stop watch; Thermometer

\section{Procedure}

Step 1: A glass cylinder was filled with water up to a height of $15 \mathrm{~cm}$.

Step 2: The temperature of water was maintained at $25 \pm 1^{\circ} \mathrm{C}$ using hot water and ice. Check the temperature using a thermometer.

Step 3: Each mouse was administered either a) none (control), b) $2 \%$ aqueous Tween 80 suspension (vehicle control), or c) extract (different doses: 100, 200, or $400 \mathrm{mg} / \mathrm{kg}$ orally once daily for 14 days) or d) fluoxetine. On the day of forced swimming test, vehicle, extract or fluoxetine was administered $30 \mathrm{~min}$ before the test.

Step 4: Thirty minutes later, the mouse was subjected to the behavioral test. the motoric activity of the mouse, which is placed in a pool of

Step 5: During the test session, the immobility time was recorded by blind observer who has been trained for the observation

Step 6: The total duration of immobility was measured during the $6 \mathrm{~min}$ test; for the first $2 \mathrm{~min}$ the animal was allowed to adjust to the new conditions; after these $2 \mathrm{~min}$, the immobility time that alternated with conditions of enhanced motor activity was measured.

Note

1. The height of the cylinder should be high enough to prevent the mouse from escaping from the cylinder.

2. The test was conducted in a dim lighted room and each mice was used only once in the test.

3. Shorter immobility time is an indicator of the stronger antidepressant effect of the tested substance.

4. The mouse was considered immobile when neither hind leg was moving nor the mice were slightly hunched forward.

5. The test is a relatively short and low cost behavioral test. It does not require any training of the mouse and can be conducted with minimal equipment.

References

Porsolt et al., 1978; Aslam, 2016

The behavioral profiles were assessed daily after single dose and after repetitive administration of the extract for continuously 14 days (once daily). group was treated with $2 \%$ aqueous Tween 80 suspension which were used as vehicle for tail suspension test model. Another three groups were treated with the prepared extract at doses of 100, 200, $400 \mathrm{mg} / \mathrm{kg}$ under the same conditions $30 \mathrm{~min}$ before antidepressant testing/activity via oral route once daily for 14 days. The last group was treated with imipramine (standard drug) 30 min before behavioral test.

\section{Locomotor activity}

Animals were placed in the digital actophotometer (Inco, India), which consists of a cage which was $30 \mathrm{~cm}$ long and $30 \mathrm{~cm}$ deep with a wire mesh at the bottom. A continuous beam of light from about six lights was made to fall on corresponding photoelectric cell. The photoelectric cell got activated when an animal crossed the beam of light and thereby cuts off the rays of light falling on it. These cutoffs were counted for a period of $5 \mathrm{~min}$.

Actophotometer: One group was control naive intact mice and another group was treated with $2 \%$ aqueous tween 80 suspension which was used as vehicle for actophotometer. Another three groups were treated with the prepared extract at doses of $100,200,400 \mathrm{mg} /$ $\mathrm{kg}$ under the same conditions $30 \mathrm{~min}$ before antidepressant testing via oral route for 14 days once daily. The last group was treated with standard drug diazepam $(2 \mathrm{mg} / \mathrm{kg}) 30$ min before test.

\section{Behaviors evaluation}

\section{Neurotransmitter measurements}

On day 14, experimental animals were sacrificed by cervical dislocation (within $5 \mathrm{~min}$ ) after being exposed to antidepressant models. The samples of brain were collected immediately on an ice plate. The brain tissue was weighed, homogenized by using cold $n$-butyl alcohol at a 1:10 volume, shaken well for $5 \mathrm{~min}$ and centrifuged at $3,000 \times \mathrm{g}$ for $5 \mathrm{~min}$. Both $5 \mathrm{~mL}$ of $n$ heptane and $0.1 \mathrm{~mol} / \mathrm{L} \mathrm{HCl}$ were added to the supernatant. After this the mixture was vortexed for $5 \mathrm{~min}$ and then re-centrifuged at 3,000 $\times \mathrm{g}$ for another $5 \mathrm{~min}$. Serotonin, norepinephrine, and dopamine was found in the water phase and 5-HIAA, a 5-HT metabolite were present in the organic phase. The amines were estimated by flourimetric method (Welch and Welch, 1969; Jacobowitz and Richardson, 1978).

\section{Estimation of norepinephrine and dopamine}

The water phase $(1 \mathrm{~mL})$ was added to $1 / 15 \mathrm{~mol} / \mathrm{L}$ of phosphate saline buffer (1.7 mL, pH 7.2). To this, $0.1 \mathrm{~mL}$ of iodine reagent was added and allowed to stand for another $2 \mathrm{~min}$, followed by addition of $0.5 \mathrm{~mL}$ of alkaline sodium sulfite solution and $0.6 \mathrm{~mL}$ of $6 \mathrm{~mol} / \mathrm{L}$ glacial acetic acid was added after $2 \mathrm{~min}$. Now the mixture was boiled for $20 \mathrm{~min}$, followed by cooling and finally fluorescence of norepinephrine was read at $385 / 475 \mathrm{~nm}$, the dopamine fluorescence at 322/370 nm 
(Welch and Welch, 1969; Jacobowitz and Richardson, 1978).

\section{Estimating of serotonin}

The aqueous phase $(0.2 \mathrm{~mL})$ was added to $O$-phthalaldehyde reagent $(0.25 \mathrm{~mL})$. The fluorophore was developed by heating to $100^{\circ} \mathrm{C}$ for $10 \mathrm{~min}$. After the samples reached equilibrium with the ambient temperature, readings were taken at wavelengths of $360-470 \mathrm{~nm}$ in the spectrofluorometer (Balamurugan et al., 2009).

\section{Statistical analysis}

The study data are represented as mean \pm SEM. The comparison between before and after treatment was made with Student's t-test. Data were analyzed by using a ANOVA (One-way analysis of variance) followed by Dunnett's test.

\section{Results}

\section{Phytochemistry}

The results of phytochemical screening indicated the presence of flavonoids in the extract (Table I).

\section{Behaviors evaluation}

It was observed that both single and even repetitive administrations of vehicle did not produce any significant change in the immobility time in forced swimming and tail suspension model. But single and repetitive administration of fluoxetine and imipramine significantly decreased the immobility time in both models $(\mathrm{p}<0.05)$ (Table II). The single administration of all extracts of $C$. limetta viz. petroleum ether, chloroform and aqueous at all dosage range used failed to show any significant changes on the percentage of changes of immobility time but the methanolic extract at dose of $200 \mathrm{mg} / \mathrm{kg}$ and $400 \mathrm{mg} / \mathrm{kg}$ markedly decreased the immobility time in both the models after repeated once daily treatment for 14 days (Table II). The behaviors assessments were performed within a time span of 30 min after the single and repetitive treatment on $1^{\text {st }}$ and $14^{\text {th }}$ day.

The effects of extract on spontaneous locomotor activity (alertness) in mice are shown in Table III. The methanol extract administered at the doses of 100, 200 and 400 $\mathrm{mg} / \mathrm{kg}$ did not modify any considerable effect on locomotor activity in mice i.e. no sedation was induced by the methanolic extract of C. limetta.

\section{Brain serotonin, norepinephrine and dopamine levels}

The methanolic extract $(200 \mathrm{mg} / \mathrm{kg})$ of C. limetta to mice significantly increased the brain serotonin $(35 \pm 4.5 \mu \mathrm{g} /$ g protein), norepinephrine $(29 \pm 3.8 \mu \mathrm{g} / \mathrm{g}$ protein) and dopamine $(23 \pm 3.7 \mu \mathrm{g} / \mathrm{g}$ protein) levels when compared with control group $(19 \pm 2.3,17 \pm 2.7$ and $11 \pm 2.6 \mu \mathrm{g} / \mathrm{g}$ protein) respectively (Figure 1 ).

\section{Discussion}

The results of our experimental study depicted that the

\begin{tabular}{|c|c|c|c|c|}
\hline \multicolumn{5}{|c|}{ Table I } \\
\hline \multicolumn{5}{|c|}{ Phytochemical screening of leaves extract of $C$. limetta } \\
\hline \multirow[b]{2}{*}{ Index } & \multicolumn{4}{|c|}{ Inference } \\
\hline & Petroleum ether & Chloroform & Methanol & Aqueous \\
\hline \multicolumn{5}{|l|}{ Test for alkaloids } \\
\hline Dragendorff's reagent & - & - & - & - \\
\hline Mayer's test & - & - & - & - \\
\hline Hanger's reagent & - & - & - & - \\
\hline \multicolumn{5}{|l|}{ Test for flavonoids } \\
\hline Lead acetate test & - & - & ++ & + \\
\hline Sodium hydroxide test & - & - & ++ & ++ \\
\hline \multicolumn{5}{|l|}{ Test for tannins } \\
\hline Bromine water test & - & - & - & - \\
\hline Dilute iodine solution test & - & - & - & - \\
\hline \multicolumn{5}{|l|}{ Test for triterpenoid } \\
\hline Liebermann-Burchard's test & ++ & + & - & - \\
\hline \multicolumn{5}{|l|}{ Test for carbohydrate } \\
\hline Molisch's reagent & - & - & - & + \\
\hline Fehling solution & - & - & - & + \\
\hline Benedict's reagent & - & - & - & + \\
\hline
\end{tabular}


Table II

Effect of methanolic extract of C. limetta on immobility time in mice

\begin{tabular}{|c|c|c|c|c|}
\hline \multirow[t]{3}{*}{ Treatment } & \multicolumn{4}{|c|}{ Immobility period } \\
\hline & \multicolumn{2}{|c|}{ Forced swimming test } & \multicolumn{2}{|l|}{ Tail suspension test } \\
\hline & Day 1 & Day 14 & Day 1 & Day 14 \\
\hline Naive & $190.3 \pm 6.4$ & $191.3 \pm 5.7$ & $186.5 \pm 7.2$ & $187.4 \pm 4.7$ \\
\hline Control (2\% Tween 80$)$ & $186.2 \pm 5.7$ & $192.4 \pm 3.5$ & $180.2 \pm 8.9$ & $173.8 \pm 8.2$ \\
\hline Extract $(100 \mathrm{mg} / \mathrm{kg})$ & $143.7 \pm 8.3$ & $97.2 \pm 5.2$ & $157.8 \pm 8.2$ & $101.2 \pm 1.4$ \\
\hline Extract $(200 \mathrm{mg} / \mathrm{kg})$ & $112.5 \pm 7.9 \mathrm{a}$ & $55.6 \pm 4.7 \mathrm{a}$ & $119.6 \pm 5.1^{\mathrm{a}}$ & $69.2 \pm 2.3^{a}$ \\
\hline Extract $(400 \mathrm{mg} / \mathrm{kg})$ & $110.4 \pm 3.1^{\mathrm{a}}$ & $63.1 \pm 7.9 \mathrm{a}$ & $121.0 \pm 3.4^{\mathrm{a}}$ & $77.2 \pm 2.4^{\mathrm{a}}$ \\
\hline $\begin{array}{l}\text { Imipramine }(15 \mathrm{mg} / \mathrm{kg}) \text { or fluoxetine } \\
(20 \mathrm{mg} / \mathrm{kg})\end{array}$ & $87.6 \pm 8.6^{a}$ & $42.3 \pm 2.4^{a}$ & $79.6 \pm 3.7^{a}$ & $37.0 \pm 4.9 a$ \\
\hline
\end{tabular}

Table III

Effect of methanolic leaves extract of C. limetta on spontaneous locomotors activity in mice

\begin{tabular}{|c|c|c|}
\hline \multirow[t]{2}{*}{ Treatment } & \multicolumn{2}{|c|}{$\begin{array}{c}\text { Activity counts } \\
\text { (Cutoff time } 5 \mathrm{~min} \text { ) }\end{array}$} \\
\hline & $\begin{array}{c}\text { Before } \\
\text { treatment }\end{array}$ & $\begin{array}{l}\text { After } 30 \mathrm{~min} \\
\text { of treatment }\end{array}$ \\
\hline Naive & $173 \pm 13$ & $180 \pm 15$ \\
\hline Control ( $2 \%$ Tween 80$)$ & $176 \pm 16$ & $189 \pm 09$ \\
\hline Extract $(100 \mathrm{mg} / \mathrm{kg})$ & $245 \pm 20$ & $231 \pm 11$ \\
\hline Extract $(200 \mathrm{mg} / \mathrm{kg})$ & $206 \pm 15$ & $233 \pm 19$ \\
\hline Extract $(400 \mathrm{mg} / \mathrm{kg})$ & $190 \pm 18$ & $201 \pm 23$ \\
\hline Diazepam (2 mg/kg) & $215 \pm 13$ & $72 \pm 27^{a}$ \\
\hline
\end{tabular}

extract can significantly decrease immobility time in both the behavioral test without showing sedative effect (decrease in alertness). It was observed that after 14 days of treatment the extract can produce anti-depressant activity at the dose of $200 \mathrm{mg} / \mathrm{kg}$ in the tested models whereas less significant changes were observed at low and high doses. The decrease in immobility time observed in this study depicts the real antidepressant like activity of the extract. Previous studies demonstrated that many neurotransmitters are involved to play a role in the pathophysiology of depression. It has been proved by numerous studies that antidepressant drugs, such as fluoxetine, aids in facilitating the action of serotonin. Because of this it is widely used as antidepressant and also agreed with animal studies, such as forced swimming test (Lucki, 1997). Further it was demonstrated that swimming behaviour shown by animals was sensitive to certain serotonergic compounds like SSRI (e.g. fluoxetine) (Detke et al., 1995).
Based on these observations, it can be supposed that the extract which can decrease the immobility time and simultaneously increases swimming behavior in the animals exposed to these paradigms can always exert its effect through a mechanism similar to that of the fluoxetine via the serotonin system. It was also found that the decrease in immobility was under the influence of motor behavior and sedative effect. We also determined the effect of plant extract on these motor behaviors and sedation. The results of the present study clearly showed that the extract did not produce any significant changes on alertness.

Analysis of the neurohormonal data supports the behavioral models results as well. There is now considerable evidence to implicate the serotonergic system with depression. The serotonergic system has been implicated in the changes in energy, cognitive functioning, sleep, mood, appetite and libido which is commonly seen in depression and affective disorders. Thus, decreased serotonin activity is always associated with depression and the most effective antidepressants have been shown to increase the functioning of serotonin in the brain. In addition, low activity of serotonin may also permit the dysregulation of other neurotransmitters, including norepinephrine (Ninan, 1999). In this study, the extract showed similar effects like imipramine which is a tricyclic antidepressant by causing inhibition of serotonin, norepinephrine and dopamine reuptake. It might be possible that the extract exert any one of these mechanism for antidepressant like activity. Preliminary phytochemical screening of crude methanol extract showed the presence of flavonoids. Flavonoids possess multiple neuroprotective actions in treating central nervous pathophysiological conditions including depression and it was reported that they possess potent antidepressant property via central serotonergic and noradrenergic system (Yi et al., 2010). 

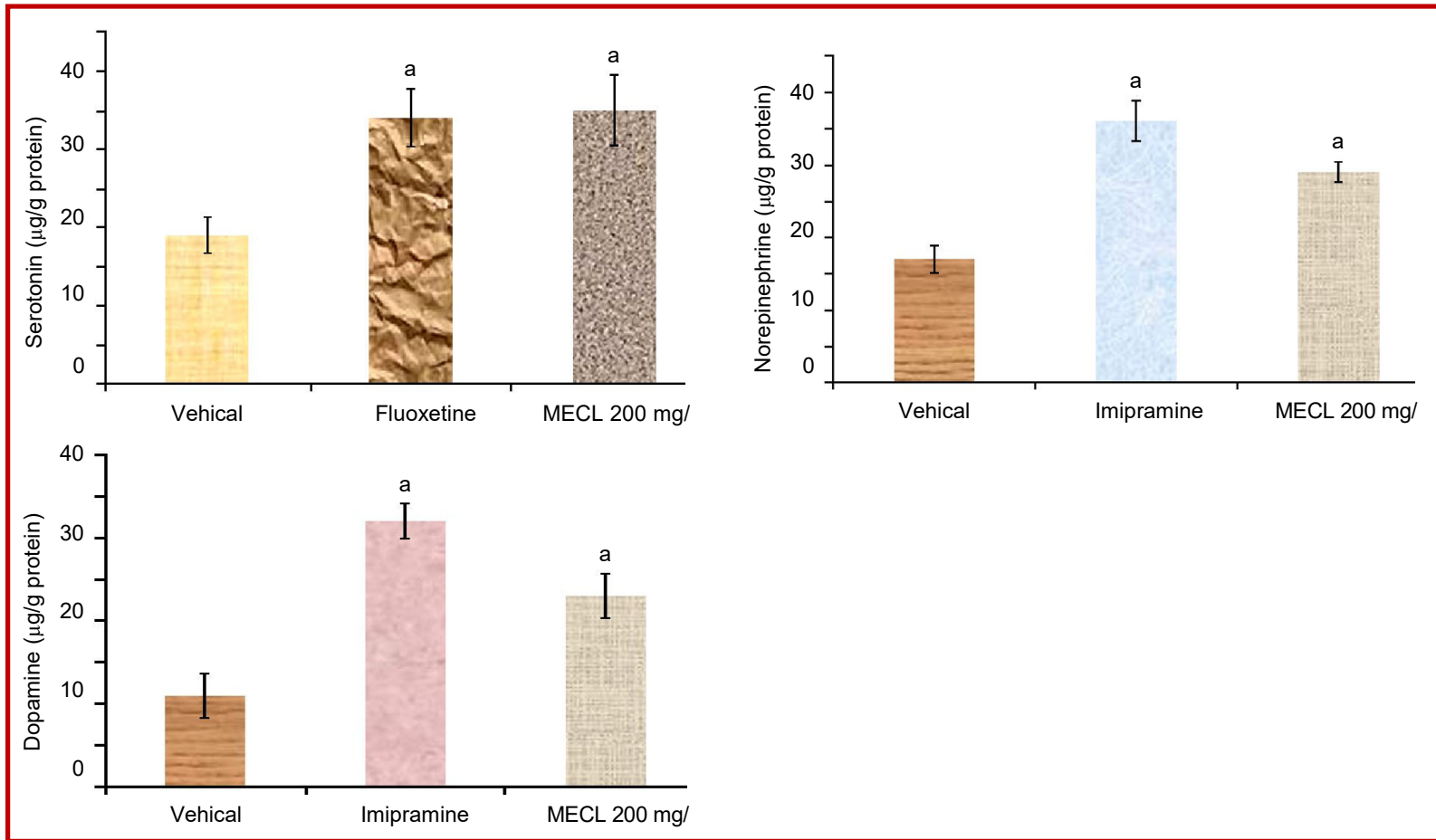

Figure 1: Effect of methanolic leaves extract C. limetta $(200 \mathrm{mg} / \mathrm{kg})$ on serotonin $(\mathrm{A})$, norepinephrine (B) and dopamine (C) after the trial of antidepressant model

All values are mean $\pm \mathrm{SEM} ; \mathrm{n}=6$; ${ }^{\mathrm{a}} \mathrm{p}<0.05$ compared to control

\section{Conclusion}

Flavonoids present in the methanol extract of C. limetta produces antidepressant effect in mice mediating an interaction through serotonergic, dopaminergic and noradrenergic system.

\section{Ethical Issue}

All experiment procedures and protocol used in the study were reviewed and approved by University Ethical Committee reference No. 828/AC/04/CPCSEA. Acute oral toxicity study of $C$. limetta was carried out in Swiss albino mice of either sex according to OECD guidelines No. 423.

\section{Conflict of Interest}

Authors declare that they have no conflict of interest.

\section{Acknowledgement}

We hereby acknowledge Maharishi Markandeshwar (Deemed to be University) for financial support.

\section{References}

Albach RF, Juarez AT, Lime BJ. Time of naringin production in grapefruit. J Am Soc Hortic Sci. 1969; 94: 605-09.
Akindele AJ, Adeyemi OO. Evaluation of the antidiarrhoeal activity of Byrsocarpus coccineus. J Ethnopharmacol. 2006; 108: 20-25.

Aslam M. Forced swim test in mice: A common animal model of depression. Bangladesh J Pharmacol. 2016; 11: 28-29.

Balamurugan G, Dharan M, Rajan S. Anti-epileptic activity of poly herbal extract from Indian medicinal plants. J Sci Res. 2009; 1: 153-59.

Bhattacharya SK, Bhattacharya A, Sairam K, Ghosal S. Anxiolytic-antidepressant activity of Withania somnifera glycowithanolides: An experimental study. Phytomedicine 2000; 7: 463-69.

Cao G, Sofic E, Prior RL. Anti-oxidant and pro-oxidant behavior of flavonoids: Structure-activity relationships. Free Radic Biol Med. 1997; 22: 749-60.

Castillo J, Benavente O, Del Rio JA. Naringin and neohesperidin levels during development of leaves, flower buds, and fruits of Citrus aurantium. Plant Physiol. 1992; 99: 67-73.

Detke MJ, Rickels M, Lucki I. Active behaviors in the rat forced swimming test differentially produced by serotonergic and noradrenergic antidepressants. Psychopharmacology 1995; 21: 66-72.

Edeoga H O, Okwu DE, Mbaebie BO. Phytochemical constituents of some Nigerian medicinal plants. Afr J Biotechnol. 2005; 4: 685-88.

Gold PW, Goodwin FK, Chrousus GP. Clinical and biochemical manifestations of depression: Relation to the neurobiology of stress. N Engl J Med. 1988; 319: 348-53. 
Hadizadeh F, Ebrahimzadeh MA, Hosseinzadeh H, MotamedShariaty V, Salami S, Bekhradnia AR. Antidepressant and antioxidant activities of some 2-benzoxazolinone derivatives as bupropion analogues. Pharmacologyonline 2009; 1: 33135.

Harborne JB, Williams CA. Advances in flavonoid research since 1992. Phytochemistry 2000; 55: 481-504.

Jacobowitz DM, Richardson JS. Method for the rapid determination of norepinephrine, dopamine and serotonin in the same brain region. Pharmacol Biochem Behav. 1978; 8: 51519.

Jourdan PS, McIntosh CA, Mansell RL. Naringin levels in citrus tissues. II. Quantitative distribution of naringin in Citrus paradisi Macfad. Plant Physiol. 1985; 77: 903-08.

Kawaii S, Tomono Y, Katase E, Ogawa K, Yano M. Quantitation of flavonoid constituents in citrus fruits. J Agric Food Chem. 1999; 47: 3565-71.

KunduSen S, Saha P, Bhattacharya S, Bala A, Mazumder UK, Gupta M, Haldar PK. Evaluation of in vitro antioxidant activity of Citrus limetta and citrus maxima on reactive oxygen and nitrogen species. Pharmacologyonline 2010; 3: 850-57.

Lucki I. The forced swimming test as a model for core and component behavioral effects of antidepressant drugs. Behav Pharmacol. 1997; 8: 523-32.

Ninan PT. The functional anatomy, neurochemistry, and pharmacology of anxiety. J Clin Psychiat. 1999; 60: 12-17.

Perez YY, Jimenez-Ferrer E, Alonso D, Botello-Amaro CA, Zamilpa A. Citrus limetta leaves extract antagonizes the hypertensive effect of angiotensin II. J Ethnopharmacol. 2010; 128: 611-14.

Porsolt RD, Anton G, Blavet N, Jalfre M. Behavioral despair in mice: A new model sensitive to antidepressant treatments. Eur J Pharmacol. 1978; 47: 379-91.
Rabiei Z, Naderi S, Rafieian-Kopaei M. Study of antidepressant effects of grape seed oil in male mice using tail suspension and forced swim tests. Bangladesh J Pharmacol. 2017; 12: 397 -402 .

Rojas P, Serrano-Garcia N, Medina-Campos ON, PedrazaChaverri J, Ogren SO, Rojas C. Antidepressant-like effect of a Ginkgo biloba extract (EGb761) in the mouse forced swimming test: Role of oxidative stress. Neurochem Int. 2011; 59: 628-36.

Sharma R, Nain P. Evaluation of antidepressant like activity of Emblica Officinalis fruit extract on mice. J Pharm Res. 2011; 4: 514-16.

Steru L, Chermat R, Thierry B, Simon P. The tail suspension test: A new method for screening antidepressants in mice. Psychopharmacol. 1985; 85: 367-70.

Trease GE, Evans WC. Textbook of pharmacognosy. 15 $5^{\text {th }}$ ed. London, Balliere Tindall, 2002.

Tripoli E, Guardia ML, Giammanco S, Majo DD, Giammanco M. Citrus flavonoids: Molecular structure, biological activity and nutritional properties, A review. Food Chem. 2007; 104: 466-79.

Welch AS, Welch BL. Solvent extraction method for simultaneous determination of norepinephrine, dopamine, serotonin, and 5-hydroxyindoleacetic acid in a single mouse brain. Anal Biochem. 1969; 30: 161-79.

Yi L, Li C, Zhan X, Cui C, Xiao F, Zhou L, Xie Y. Involvement of monoaminergic system in antidepressant-like effect of flavonoids naringenin in mice. Prog Neuropsychopharmacol Biol Psychiatry. 2010; 34: 1223-28.

Yu ZF, Kong LD, Chen Y. Antidepressant activity of aqueous extracts of Curcuma longa in mice. J Ethnopharmacol. 2002; 83: 161-65. 